\title{
Göç ve Demokrasinin Geleceği
}

\author{
DOI: 10.26466/opus.592954
}

\begin{abstract}
$*$
\section{Fethi Nas*}

*Dr. Öğr. Üyesi Bartın Üniversitesi, Edebiyat Fakültesi, Sosyoloji Bölümü Bartın / Türkiye E-Posta: fethinas@yahoo.com

ORCID: 0000-0001-6464-5615
\end{abstract}

\section{Öz}

Yoğun bir göç hareketine maruz kalan ülkelerde siyasal, ekonomik, sosyal ve kültürel farklilıklarda artı̧lar görülmektedir. Bu farklıların bir arada varlı̆̆ın sürdürmesi, uluslar arası, ulusal ve yerel düzeyde belirlenen politikalarla mümkündür. Ulus devlet anlayışına sahip demokratik ülkelerde, göçlerden kaynaklanan yeni tür sorunlar ortaya çıkmaktadır. Bu sorunlar arasında yabancı düşmanlığı ve aşırı sağ partilerin yükselişi dikkat çekmektedir.Bu tür eğilimlerin artış göstermesi, demokratik ilkelerin geleceği açısından son derece tehlikelidir. Devlet ve hükümetlerin, ülkeye çeşitli yollardan gelen göçmenlerin yaşam koşullarmı düzenlemesi, toplum ile bütünleștirilmesi ve kamuoyunun bu konuda bilinçlendirilmesi konusunda demokratik değerler çerçevesinde hareket etmesi önemlidir. Aksi takdirde toplumsal yapıda farklllklara karşı kutuplaştırıcı ideolojiler baș gösterecek ve evrensel barışın tesisi zorlaşacaktır. Bu amaçla çalışmada, göç ve demokrasi ile ilgili literatürde yer alan çalışmalar ile uluslar arası kuruluşların yayınladığı raporlar incelenmiştir. Günümüz dünyasında göç hareketlerinin artarak devam ettiği ve göçmen sayısının özellikle gelişmiş ve gelişmekte olan ülkelerde arttığı bilinmektedir. Dolayısıyla gö̈cmen veya yabancı olarak kabul edilen ve toplumsal bir gerçeklik haline gelmiş olan bireylerin, mümkün olduğunca demokrasinin sağlamış olduğu olanaklarla tanıştırılmasının faydalı olacağı düşünülmektedir.

Anahtar Kelimeler: Göç, Demokrasi, Yurttaşlık, Seçme ve Seçilme Hakkı, Çokkültürcülük. 


\title{
Migration and the Future of Democracy
}

\begin{abstract}
There has been an increase in political, economic, social and cultural differences that have been subjected to intensive migration. The coexistence of these differences is possible with the policies agreed at international, national and local level. In democratic countries which support the nation-state approach, new problems arise from migrations. Among these problems, xenophobia and the rise of right wing parties are the most important. The increase of such tendencies is extremely dangerous for the future of democratic principles. It is important that states and governments act within the framework of democratic values to regulate the living conditions of immigrants coming to the country in various ways, to integrate them with society and to raise public awareness on this issue. Otherwise, polarizing ideologies will emerge against differences in social structure and the establishment of universal peace will be difficult. For this purpose in the study the literature on migration and democracy and some reports published by international organizations are examined. In today's world, it is known that migration movements continue to increase and the number of migrants increases especially in developed and developing countries. Therefore, it is thought to be beneficial to introduce individuals who are accepted as immigrants or foreigners and have become a social reality with the opportunities provided by democracy as much as possible in such countries.
\end{abstract}

Keywords: Migration, Democracy, Citizenship, Suffrage, Multiculturalism. 


\section{Giriş}

Son yıllarda özellikle gelişmiş ve gelişmekte olan ülkelerde göçün, gündemin en önemli konuları arasında yer aldığı görülmektedir. Eğitim sisteminin düzenlenmesinden dini hayata dair uygulamalara, ekonomik yatırımlardan iskân politikalarına varıncaya kadar pek çok alanda ve faaliyette, göçmenlerin ülke içerisindeki konumlarını göz önünde bulundurma zorunluluğu ortaya çıkmıştır. Özellikle demokrasi ile yönetilen ülkelerde siyasal partiler, göçmenlere yönelik tutumları itibariyle ikiye ayrılmış bulunmaktadır. Bazı siyasal partiler göçmen akınlarını engellemeyi ve göçmenleri sınır dışı etmeyi programlarına alırken, karşıt taraftaki partiler göçmenlere dair daha yumuşak politikaların izlenmesi gerektiğine vurgu yapmaktadır. Göçmen karşıtı hareketlerin yoğunlaştığ 1 birinci türdeki partiler, göçmenlere kapı aralayan hükümetlerin göç politikasını radikal biçimde eleştirerek, göçmenlerin toplumsal düzeni tehdit ettiğini ve toplumda çeşitli huzursuzluklara yol açtığını iddia etmektedir. Diğer partiler ise göçmenlerin ülkenin kültürüne ve ekonomisine sağlayacağı faydaları göz önünde bulundurarak, göçmenlerin ülkenin kalkınmasında olumlu bir etki sağlayacağını savunmaktadır.

$\mathrm{Bu}$ bakımdan ele alındığında göç ve göçmen konularının kamuoyu tartışmalarında adeta merkezi bir konuma geldiği ve gittikçe tırmanmaya devam eden küresel bir krize dönüştüğü görülmektedir. Küreselleşme süreci ile birlikte ekonomik ve sosyal sorunlara yol açan çeşitli değişmeler, insanları göç etmeye iten faktörleri ortaya çıarmıştır. Eldeki veriler ve gözlemler, göçmen hareketliliğinin şiddet olaylarının ve yoksulluğun sıkça görüldüğü Ortadoğu Ülkeleri, Kuzey ve Orta Afrika ülkelerinde yoğunlaştığını göstermektedir (Wittenberg, 2017). Bu konuya dair en etkili örneklerin başında Suriye Krizi yer almaktadır. Suriye' de 2010 yılından itibaren yaşanmaya başlanan iç çatışmalar; Lübnan, Türkiye ve Ürdün olmak üzere Avrupa Birliği ülkelerini ciddi sorunlar ile karşı karşıya getirmiştir. Doğası gereği göçler, ulus ötesi bir hareket olma özelliğine sahip olduğundan ulusal ve yerel düzeyde devlet ve hükümet politikalarını yeniden şekillendiren, ekonomik faaliyetlere etki eden çokkültürcülük ve yurttaşlık kavramlarına dair tartışmaları farklı boyutları ile yeniden gündeme getiren bir potansiyel taşımaktadır. 
Farklı ülkelerde göçmenler ile ilgili değişen politikalar hayata geçirilmektedir. Bunlar arasında en belirgin olanları Avrupa Birliğinde ortaya çıkmıştır. İkinci Dünya Savaşından bu yana Batılı demokrasilerin siyasal bakış açılarını etkileyen en önemli sorunların başında günümüzde yaşanan göçler gelmektedir. Avrupa ülkeleri maruz kaldıkları göç hareketlerinin etkisini mümkün olduğunca azaltmaya çalışmaktadır. Avrupa genelinde göçmenlere dair genel eğilimin ne olduğu tam olarak bilinmemekle birlikte, göçmen karşıtı hareketlerin yükselişte olduğunu söylemek mümkündür (Estevens, 2018). Avrupa Birliği şemsiyesi altında yer alan hükümet ve siyasi partilerin çoğu, karşı karşıya geldikleri göç akımlarını engellemek amacıyla sınırlayıcı göç politikalarına yönelmişlerdir. Öyleki göçmen karşıtlı̆̆ını savunan parti ve liderlerin, özellikle Avrupa ve Amerika Birleşik Devletleri'nde göstermiş olduğu seçim başarısı, göçün siyasal ve ekonomik söylemde taşıdı̆̆ı önemi göstermiştir. 2016 yılında ABD’de yapılan başkanlık seçiminde Donald J. Trump göçmen karşıtı yürüttüğü kampanya ile başkanlık seçimini kazanmıştır. Trump yönetimi seçimden sonra özellikle Müslüman ülke yurttaşlarının ABD'ye girişlerine sınırlamalar getirmiş ve Meksikalı göçmenlere karşı sınırda duvar inşa ettirmiştir. Bununla ilişkili olarak ABD'de yabancı düşmanlığı ve göçmen karşıtı hareketlerde bir artış görülmüştür (Verea, 2018). Geleneksel göç ülkesi olduğu bilinen diğer ülkelerde ise göçe yönelik farklı uygulamalara rastlanmaktadır. Örneğin Avustralya'da göç politikaları, vasıflı ve vasıfsız göçü birbirinden ayırmaya odaklanmıştır. Vasıflı ve eğitimli göçmenlerin ülkeye gelişi teşvik edilirken, vasıfsız göçmenlerin ülkeye girişi sınırlandırılmıştır. Kanada ise farklı olarak, birçok göçmeni ve mülteciyi kabul eden çok kültürlü bir göç politikasını benimsemiştir.

Ulaşmış olduğu yoğunluk itibariyle göç hareketleri ve buna ilişkin tartışmalar, dünya genelinde adeta bir ikilem ortaya çıkarmıştır. Bu ikilem özellikle demokratik toplumlar olarak bilinen ülkelerde siyasetçilerin göç sorununa yönelik geliştirdiği argümanlarla ilişkilidir. Göç politikaları ya çokkültürcülüğü beraberinde getirmekte ya da toplumsal düzeyde bir kutuplaşmaya yol açmaktadır. Göç alan ülkelerde toplumsal kurumlar ve süreçler göçmenlerin yaşantılarını sürdürebilmesi yönünde çeşitli politikaların ve uygulamaların hayata geçirilmesini zorunlu kılmaktadır. Fukuyama (2006) günümüzde yaşanan göçlerin, ulusal kimlikleri ve 
demokrasileri önemli ölçüde etkilediğini ve toplumları kendilerini "Biz kimiz?" sorusu ile sorgulamaya ittiğini dile getirmektedir. Ona göre, futbol ve içki içmek gibi bir kültürün ortak öğelerinin neler olduğunu belirlemek kolaydır fakat ulusal bir tarihin hangi yönlerinin önemli olduğunu belirlemek oldukça zordur. Bundan dolayı günümüz toplumları daha ciddi bir kimlik tartışmasına yöneleceklerse, daha büyük bir topluluğa üye olmanın ne demek olduğunu tanımlayan pozitif erdemleri ortaya çıkarması zorunludur.

\section{Göç ve Yabancı Düşmanlığı}

Küreselleşme süreci hem sermaye hem de emek gücünün özgür biçimde ulus devletlerin sınırlarını aşarak hareket etmesinin önünü açmıştır. Yerel bir çoğunluk veya göçmen bir azınlık; ulusal, etnik veya dini kimliklerinin tehdit altında olduğunu algıladığında, bu özelliklerini koruma yönünde bir refleks gerçekleştirirler. Avrupa Birliği ülkelerine son yıllarda yoğun bir göçmen akımının yönelmiş olması, AB üyesi ülkelerin yurttaşlarının siyasi düşüncelerinde ve oy verme tercihlerinde yeni bir bakış açısı ve daha da ötesi $\mathrm{AB}$ ilkeleri ve küreselleşmenin başarısını doğrudan etkileyen muhalif yönde eğilimleri ortaya çıkarmıştır. Göç alan pek çok ülkede küreselleşme karşıtı hareketler buna paralel biçimde artış göstermektedir. $A B$ ülkelerinde göç hareketlerinin, son 3 yılda popülist sağcı-muhafazakâr partilerin ve eğilimlerin artışına etkisi araştırılmıştır. Buna göre $\mathrm{AB}$ ülkelerinde toplam nüfus içinde göçmen nüfusu \%22'yi aştığı anda popülist sağcı partilerin oy oranı $\% 50$ 'ye yaklaşmaktadır. Bu oy oranı ise demokratik bir yönetimde bir partinin tek başına iktidar olmasına yeterlidir. Bu ülkelerde yurttaşların popülist sağ partilere eğilimi arttıkça, göçmenlere karşı toleransları azalmakta ve göçmen karşıtlığı artmaktadır (Podobnik, vd., 2017). Başka bir araştırmada ise popülist sağ partilerin oy artışlarının ve göçmenlere karşı olumsuz tutumların sadece ulusal, etnik ve kültürel özelliklerle ilişkili olmadığını, bunların yanı sıra ekonominin, eğitim seviyesinin, inanışların ve psiko-sosyal özelliklerin de belirleyici olduğunu göstermiştir (Hainmueller ve Hopkins, 2014). Yoğun göç hareketlerinin yaşandığ Batı toplumlarındaki otoriter popülist ideolojilerin yükselişini sadece göçmenlere yönelik olumlu hükümet politikalarıyla ilişkilendirmek mümkün değildir, bununla birlikte sosyal 
yapıdaki değişmelerin ve liberal değerlere karşı güçlü bir kültürel tepkinin varlığ göz önünde bulundurulmalıdır.

Göç alan ülkeler, zaman içinde demografik yapının değişmesi ile birlikte çokkültürlü bir yapıya dönüştüğünden ulusal kimlik sorunları artış göstermektedir. Bu yüzden göç dalgaları toplumun muhafazakâr kesimlerini oluşturan farklı grupları arasında yeni türden gerilimlere ve siyasal dinamiklere yol açmaktadır. Son yıllarda Batı toplumlarında genel olarak göçmenlerin çoğunun Müslüman ülke kökenlilerden oluşması ile ilgili olarak İslamofobi ve yabancı düşmanlığı gibi bakış açıları oluşmuş bulunmaktadır (Kılıç, Saharo ve Sauer 2008). Bu bakış açıları çeşitli önyargılarla yoğrulmuş bir takım düşünceler haline gelmekte, göçmen veya yabancıların ülke açısından bir tehdit kaynağı olduğu ileri sürülmektedir. Göçmen ve yabancıların terörist gruplarla ilişkisi olduğu, ülkede yasa dışı faaliyetler yürüttüğü ve en önemlisi yerli halkın çalışma hayatını bertaraf ettikleri iddia edilmektedir (Forrester vd, 2019). Bunun gibi farklı yaklaşımlardan ötürü göçmenler, yeni geldikleri toplumda kendilerini yasal ve kültürel bakımdan yabancı, dışlanmış ve yasadışı olarak görmektedirler. Oysa göçmenlerin genel olarak nihai amac1, daha iyi yaşam koşullarına ulaşmaktır. Temel ihtiyaçlarını gidermek konusunda sorunlarla karşılaşan göçmen veya göçmen olmayan her birey, ihtiyaçlarını temin edebilmek amacıyla bazen yasadışı faaliyetlere yönelmekte veya suç örgütlerine dâhil olmaktadır. Ayrıca yasal bir statüsü olmaksızın, bir çok gelişmiş ülkede kayıt dışı istihdam edilen göçmenlerin olduğu bilinmektedir. Dolayısıyla göçmen konumundaki insanların içerisinde bulunduğu dezavantajlı konumdan, her zaman için fayda sağlayanlar vardır (De Genova, 2002). Bugüne kadar gözlemlendiği kadarıyla çok az bir göç hareketi süreli ve dönemsel olarak gerçekleşmiştir. Göçmenler süreli veya geçici olsa bile gittikleri yeni ülkelerden kendi ülkelerine dönmemektedirler. Yeni geldikleri ülkelerde kendilerine ait yeni bir yaşam kurmak zorunda kalmaktadırlar. Bundan dolayı atılması gereken ilk adım, göçmenlerin yasal bir statüye sahip olmalarının yollarını kolaylaştırmaktır. Göçmenlerin çoğu çalışma, barınma, eğitim, sağlık vb temel ihtiyaçlar söz konusu olduğunda bir tür ayrımcılığa maruz kalırlar ve bu tür sorunlar göçmen aileler ile çocuklarının üzerinde ilerleyen yıllarda sosyal ve psikolojik sorunlar yaşamalarına sebep olan travmatik etkiler bırakabilmektedir. Oysa yasal bir statüye sahip olan göçmenler, 
yaşadıkları toplumda bazı haklar ile sorumluluklar alabilmekte ve böylece toplum ile bütünleşmenin ilk adımlarını atmaktadırlar (Brown 2015).

Yoğun bir göç hareketine maruz kalan ülkelerin demokratik yönetim ve kurumları üzerindeki etkilerini inceleyen araştırmalarda üç farklı durum belirginleşmektedir bunlar; göç alan toplum üyelerinin taşıdı̆̆ 1 endişeler, göçlerin yoğunluğu ve göçmenlerin toplumun geneli ile uyum sağlamasına yönelik politikalardır (McLaren, 2010). Göç ve göçmenlere dair endişeler, daha çok göç alan ülke yurttaşlarının ulusal kimlik ve aidiyetleri ile toplumsal değerlerine yönelik beliren endişeler ile özdeşleşmiştir. Fakat görünürdeki bu endişelerin esas sebebi büyük ölçüde değişen ekonomik koşullar ile siyasal ve sosyal ayrıcalıklardır. Göç alan ülkelerde zaman içerisinde doğal yurttaş ve sonradan gelen yurttaş şeklinde bir ayrım oluşmaktadır. Sonradan gelen yurttaşların ulaştığı çeşitli imkânlar, öteden beri yurttaş olarak kabul edilen diğerlerinin ayrıcalıklı siyasal, sosyal ve ekonomik konumlarını olumsuz etkileyebilmektedir. Bundan dolayı demokratik kurumların göç sonrası süreçte sonradan gelenleri toplum ile bütünleştirmesi, sosyal uyuma dâhil etmesi ve çokkültürlü bir yapıyı oluşturabilmesi oldukça önemlidir. Çoğunluğu oluşturan doğal yurttaşlar bu konuda kanun koyuculara ve yöneticilere güven duyuyor ve destekliyorsa siyasal kurumların göç gibi karmaşık bir sosyal süreç ile baş etme kapasitesi daha da yükselecektir (Miller ve Listhaug 1990). Bundan dolayı yoğun göçe maruz kalan ülke hükümetlerinin birincil görevi, göçmenlere veya yabancılara karşı yurttaş olanların olumsuz algılarını ve tepkilerini azaltacak, çokkültürlü ve demokratik bir bilinci yaygınlaştırmasıdır. Aynı zamanda hükümetlerin ulusal ve uluslararası bir sorun olarak göç konusunun altından kalkabilecekleri bir mesele olduğu ile ilgili bilgilendirici mesajlar vermeleri gereklidir. Aksi takdirde göç ile ilişkili olarak yaşanan sorunlar, demokratik değerlerin işleyişini zora sokacaktır. Bunun en bariz göstergelerinden biri Britanya'da yapılan BREXITT referandumudur. BREXİT referandumunda ele alınan konulardan en hayati olanları, göçmenlerin konumu ile ilgilidir. Avrupa Birliği üyesi ülkelerde yaşayan göçmenlere yapılacak sosyal yardımların ve faydalanacakları kamu hizmetlerinin finansmanı için yurttaşlardan daha fazla vergi alınacak olmasından ötürü Britanya, Avrupa Birliği'nden ayrılma kararı almıştır. Bu konular aynı zamanda Avrupa 
Birliği üyesi ülke yurttaşlarının $\mathrm{AB}^{\prime}$ ye bakış açısını olumsuz yönde etkilemekte ve bir demokrasi projesi olarak $A B^{\prime}$ nin geleceğini tehlikeye atmaktadir (Wadsworth vd.2016).

\section{Göçmenlik ve Yurttaşlık}

Dünya genelindeki göç hareketleri, küreselleşme süreci ile birlikte geçmişte olduğundan daha fazla hissedilir hale gelmiştir. İnsanların yaşadıkları ülkeden göç etmelerine yol açan ekonomik sorunlar ve çalışma koşulları, siyasal istikrarsızlıklar ve savaşlar, insan hakları ihlalleri, iklimsel değişmeler ve doğal afetler, itici faktörler olarak kabul edilmektedir. Buna karşılık daha iyi yaşam ve çalışma koşulları, sosyal hizmetlere erişim, sağlı ve eğitim olanakları ile bireysel hak ve özgürlükler çekici faktörler arasındadır. 1980'li yıllardan itibaren Avrupa Birliği ülkeleri; Berlin Duvarı'nın yıkılması ve Sosyalist rejimlerin çöküşü ile çekici faktörlerin ön plana çıkmaya başladığı ve bu yüzden göçmen akımlarının hedefi haline gelen yerler olmuştur. Birleşmiş Milletler raporuna göre Avrupa 76 milyon, Amerika ve Kanada 54 milyon civarında göçmen barındırmaktadır (UN, 2015). Avrupa, ABD ve Kanada gibi ülkeler dünyada refah seviyesi yüksek ve demokrasinin gelişmiş olduğu bu açıdan bakıldığında çekici faktörlerin yoğunlaştığı yerler olarak görülmektedir.

20.yy'ın başından itibaren göç hareketleri dünya üzerinde küresel bir soruna dönüşmüştür. Özellikle az gelişmiş ve gelişmekte olan ülkelerden, gelişmiş ülkelere doğru bir göç hareketinin dramatik artışlarla devam ettiği bilinmektedir. Bu göç hareketinin büyük bir bölümü gönüllü göçler şeklinde gerçekleşmiş olsa da zorlama yoluyla göç hareketleri de artmaya başlamıştır. 2015 yılına ait Birleşmiş Milletler Mülteciler Yüksek Komiserliği Raporuna göre dünya üzerinde çoğunluğu Afganistan, Somali ve Suriyelilerden oluşan 20 milyon civarında insan göçmen veya mülteci konumunda yaşamını sürdürmektedir (UNHCR, 2015). Özellikle Suriye'de yaşanan çatışmalardan ötürü İkinci Dünya Savaşı'ndan bu yana en büyük mülteci sorunlarından birisi ortaya çıkmış bulunmaktadır. 2016 yılı verilerine göre beş binden fazla insan Avrupa ülkelerine ulaşmak amaciyla Akdeniz'i geçmeye çalışırken hayatını kaybetmiştir. Özellikle 
Ortadoğu'da yaşanan olaylardan ötürü, bu tür sorunların en fazla yoğunlaştı̆̆ bölge Akdeniz ve çevresi olmuştur (UNHCR, 2016).

Kontrol edilemeyen yoğun göçlerin, siyasal yapıları, sosyal uyumu ve ulusal kimlikleri sarsma riski oldukça yüksektir. Göçmenlerin toplum ile farklı düzeylerde bütünleştirilmesi yönünde merkezi yönetimlerin sarf ettiği çabalara karşılık kamuoyunda göçmen karşıtlığının yükseldiği ve siyasal tercihlerde farklı eğilimlere yönelim olduğu görülmüştür (Weldon, 2006). Bundan dolayı demokratik ülkelerde bu tür eğilimlerin ve düşüncelerin oluşmasına zemin hazırlayan koşulların göz önünde bulundurulması gereklidir. Zira göçmenlerin toplum ile bütünleştirilmesi ve uyum sağlamasına yönelik politikaların sürdürülebilirliği demokratik sistemin esnekliğini ve hazmetme kapasitesini geliştirmesi ile mümkündür. Göç alan ülkelerin göçmenleri bütünleştirme politikalarının başarısı bir dizi etkene bağlıdır. Göçmenlere yurttaşlık hakkının ve bilincinin kazandırılması, ulusal ve yerel seçimlerde göçmenlerin seçme ve seçilme haklarına sahip olması, göçmenlerin parlamentoda, siyasi partiler ve yerel yönetimler gibi kilit siyasi kurumlarda yeterince temsil edilmesi ve göçmen karşıtı siyasal partilerin yol açtığı zorlukların mümkün olduğunca azaltılması önemli etkenlerdir (Breunig vd, 2012). Bu etkenlerin hayata geçirilmesi büyük ölçüde göçmen olarak ülkeye gelen insanların hayatın her alanında daha geniş haklara sahip olmasını sağlayan yurttaşlık haklarına sahip olması ile yakından ilişkilidir.

Göçmenlerin siyasal yaşama dâhil olması ve toplum ile bütünleşmelerini zorlaştıran çeşitli engellerin ortadan kaldırılması yönünde yurttaşlık statüsü önemli bir motivasyondur. Yasal anlamda yurttaş olarak kabul edilenler, sivil ve siyasal haklara ulaşmakta, ayrımcılık ve dışlama gibi olumsuz tavır ve tutumlardan uzak kalabilmektedir. Avrupa Birliği ülkelerinde doğal yurttaş ve sonradan yurttaş olarak kabul edilenlerin siyasal katılımları ile ilgili yapılan bir araştırma sonucunda, her iki grubun siyasal faaliyetlere katılım düzeylerinin birbirlerine yakın olduğu görülmüştür. Yurttaşlığın, siyasal katılımı arttıran bir etken olduğu ve özellikle demokratik olmayan bir ülkeden gelenlerin siyasal katılımda daha aktif olduğu görülmüştür (Tuna ve Özbek, 2014, s.213). Dolayısıyla göç alan bir ülkede, göçmenlerin toplumla bütünleşmeleri, göçmenlere yurttaşlık verme konusunda istek ve düzenli bir prosedüre sahip olunması oldukça önemlidir. Devletlerin hangi koşullar altında yabancılara/göçmenlere 
yurttaşlık verilmesi gerektiği ile ilgili uygulamaları ve yasal düzenlemeleri birbirinden farklılık arz etmektedir fakat bu konuda ön plana çıkan iki yaklaşım vardır. Bunlardan birincisi yurttaşlığın kan bağı yolu (iussanqunis) ile elde edildiğini savunurken diğeri yurttaşlı̆̆ın ikamet koşullarının yerine (iussoli) getirilmesi ile ilgili olduğunu savunmaktadır (Saurer, 2017).

Avustralya, Danimarka, Fransa, Almanya, Hollanda, İngiltere ve ABD gibi yoğun göç alan bazı gelişmiş ülkeler, göçmenlerin veya yabancıların yurttaşlığa kabul edilmesi sürecinde bir yurttaşlık testi uygulamaktadırlar. Bu tür testler yurttaşlığa başvuru sayısını azaltmıştır ve nihai olarak yurttaş olarak kabul edilenlerin toplum ile bütünleşme süreçlerini ne şekilde etkilediği belirsizdir. Bazı ülkeler ise yurttaşlık başvurusu yapanlardan dil bilme, yasadışı olaylara dâhil olmama ve herhangi bir suç işlememiş olma gibi önkoşulları talep etmektedir (İnci, 2017). Esnek bir yurttaşlık politikası bulunan ülkelerde, göçmenlerin vatandaşlık talepleri ve başvuruları daha kolaydır. İrlanda, Portekiz, İngiltere ve Benelüks ülkeleri Avusturya, İsviçre ve Baltık ülkelerine göre daha esnek ve kapsayıc bir yurttaşlık politikasına sahiptir (Huddleston vd., 2015) ve neredeyse bütün ülkelerde oturma veya çalışma iznini elde eden göçmenler, bu izinlere bağlı olarak ilerleyen yıllarda bir yurttaşlık hakkı elde edeceğine inanmaktadır. Ne var ki, yoğun göç hareketleri, yurttaşlı̆̆a alma sürecini uzatmakta ve çoğu zaman olumsuz yönde etkilemektedir. Yoğun göçlerden ötürü ulusal hükümetler yurttaşlık verme süreçlerini kısıtlamakta veya çok katı kurallara bağlamak zorunda kalmaktadır. Siyasal bakımdan oluşan bu engellerin yanı sıra göçmenlerin sahip olduğu bir takım özellikler yurttaşlı̆̆a geçişleri etkilemektedir. Bu özellikler arasında göçmenlerin eğitim seviyesi, cinsiyeti, yaşı, yabancı olarak oturma süreleri, aile bağlarının varlığı/yokluğu, göç etmelerine yol açan sebepler ile geldikleri ülkelerin uluslar arası konumu etkilidir (Koslowski, 2002, s.157).

Yurttaşlık, göçmenlerin toplumsal bütünleşme sürecini hızlandırıp kolaylaştırır ayrıca yaşama tutunmaya çalıştıkları yeni topluma siyasal ve sosyal aidiyet hissi geliştirmelerinde etkilidir. Buna karşılık kimlik sorunu, toplum tarafından dışlanma ve kendi ülkesine geri dönme gibi endişeler göçmenlerin yurttaşlık taleplerini olumsuz yönde etkilemektedir. Yurttaşlık yasal ve kuramsal olarak yeni bir aidiyet, kimlik, kültür ve 
yaşam biçimi benimsemeyi zorunlu kılmasa da büyük ölçüde kendi yurttaşlı̆̆ından vazgeçmeyi, resmi dili öğrenmeyi veya bütünleşmeye yönelik etkinliklere katılımı gerektirmektedir (Hyde vd., 2013).

\section{Demokratik Bir Hak Olarak Oy Kullanma}

Demokratik yönetimlerin karakteristik özelliği özgür yurttaşların oy kullanma hakkına sahip olmasıdır. Bu hak ise hem ulusal hem de uluslar arası alanda kabul edilen temel bir ilkedir. Günümüz dünyasında temsili demokrasi ideal yönetim biçimi olarak kabul edilmekte ve tüm yurttaşların seçme ve seçilme haklarını kısıtlayan engeller azaltılmaya çalışılmaktadır. Devlet aygıtı ise bu konuda gerekli önlemleri ve teşvikleri yapmak zorundadır (Lizzeri ve Persico, 2004). Fakat küreselleşme süreci ve göç hareketleri seçme/seçilme ve oy kullanma gibi alanlarda yeni perspektifler getirmiştir. Göç alan ülkelerde yabancıların oy kullanması ile ilgili farklı uygulamalara rastlanmaktadır. Son yıllarda pek çok ülkede hükümetler ve siyasi partiler bölgesel, ulusal ve yerel düzeylerde göçmenlerin oy kullanması konusunu farklı biçimlerde ele alıp tartışmaktadır. Çoğunluk, göçmenlerin oy kullanma hakkının oturma ve çalışma izni olanlar ile oturum süresini dolduranlara verilmesi gerektiğini savunmaktadır. Bazı ülkeler, kendi seçim yasalarını revize ederek yurttaş olmayanların ve sadece oturma izni olanların oy kullanabileceği bir biçime dönüştürmüştür (Pedroza, 2015). Dünya ülkeleri arasında Avrupa Birliği ülkeleri, yurttaş olmayanların seçme ve seçilme hakkına sahip olduğu başlıca ülkelerdendir. 3 ile 5 yıl arasında Avrupa Birliği üyesi olan bir ülkede oturan göçmen veya yabancılar, yerel seçimlerde oy kullanıp aday da olabilirler. Buna rağmen Avrupa Birliği ülkeleri içerisinde seçme ve seçilme hakkına sahip olmayanların oranı 10 milyon civarındadır. Benzer bir durum ABD, Kanada, Japonya ve Türkiye için geçerlidir. Dolayısıyla milyonlarca insan yaşadığı ülkede seçme ve seçilme hakkından mahrum olarak yaşamını sürdürmektedir (Huddleston vd., 2015).

Göçmenlerin seçme ve seçilme hakları ile ilgili konu son derece çetrefillidir çünkü sadece yurttaşlık statüsüne sahip olanların oy kullanma hakkı olduğu düşüncesi ve pratiği yaygındır. Yurttaşlık her ne kadar sosyal, sivil ve siyasal hakların bir bileşkesi olarak kabul edilse de birçok ülkede göçmenlere yurttaşlık hakkı verilmeden sadece yerel düzeyde 
seçme ve seçilme hakkının tanınmasına yönelik bir eğilim vardır (Bauböck, 2005). Örneğin Japonya'da sürekli oturma iznine sahip olan yabancılar vergi ödedikleri ve topluma katkıda bulundukları sürece yerel düzeyde yapılan seçimlere katılabilirler fakat ulusal seçimlerde seçme ve seçilme hakkına sahip değillerdir. Çünkü Japon hükümetleri, yabancıların ülkenin siyasal sistemi üzerinde etkili olabileceğini ve uzun vadede bu tür bir etkinin Japon kültürünü ve ulusal kimliğini tehdit edebileceğini savunmaktadır. Bundan dolayı Japonya ve benzeri ülkeler Avrupa ve ABD gibi ülkelerle mukayese edildiğinde göçmen veya yabancılara karşı daha katı ve muhafazakâr bir ideolojiye sahiptirler (Medrzycki, 2017).

Demokratik bir hak olarak seçme ve seçilme haklarının yurttaş olmayan göçmenlere ve yabancılara verilip verilmeyeceği konusunun küresel ölçekte demokrasiyi güçlendirip güçlendirmeyeceği tam olarak bilinmemektedir. Fakat kesin olan husus bu hakların ülkelere, sosyal ve siyasal koşullara göre farklılık arz ettiğidir. Bazı siyasal akımlar oturma iznine sahip olan yabancıların seçimlere dâhil edilmesinin demokratik yönetimi daha da güçlendireceğini ve bunun demokratik yönetimlerin yerine getirmesi gereken hukuki, ahlaki ve insani bir zorunluluk olduğunu savunmaktadır (Engdahl vd, 2018). Bu argüman ise söz konusu haklara ulaşma olgunluğunun bir tür zamanlama meselesi olduğuna dayalıdır. Göçmenlerin ev sahibi ülkede kısa bir süre içerisinde demokratik kurumlar ile tanışmasının, yeni siyasal ve sosyal sisteme uyum sağlayacağ1 ve toplumla bütünleşme hızlarını arttıracağı ileri sürülmektedir bu yüzden yurttaş olmasa bile göçmenlere veya yabancılara siyasal arenada kendilerini temsil edebilecekleri bir takım olanakların verilmesi her iki taraf açısından faydalıdır (White vd. 2008). Yerel düzeyde yabancılara seçme ve seçilme hakkının verilmesi yerel yönetimlerin oluşturulması sürecinde bir yerde yaşayan insanların birbirleri ile eşit haklara sahip olduğu hissi ile yerel yönetimlere duyulan güveni ve meşruiyeti arttıran bir unsurdur. Bundan dolayı yerel düzeyde olsa bile yabancilara oy kullanma hakkının, evrensel bir ilke olarak verilmesi politikası, yurttaş olmayanlara siyasal bütünleşmeye eşit koşullarda dâhil olma fırsat ve aidiyet hissini kazandırmaktadır. Avrupa Birliğinin Göçmen Entegrasyon Politikasına göre göçmenlerin özellikle yerel düzeyde demokratik süreçlere ve bütünleşme politikalarının oluşturulmasına dâhil olması göçmenlerin Avrupa Birliği müktesebatına uyum sağlamalarını 
kolaylaştırmaktadır. Çünkü bütünleşme yerel düzeyde gerçekleşen bir süreç olarak kabul edilmektedir (European Commission 2004, s.10).

Bunun tam tersini savunan siyasal düşünceler de vardır. Bu düşünceler ise göçmenlere, ev sahibi ülkenin dilini öğrenmeden ve siyasal kültürü hakkında yeterince bilgilenmeden, oy kullanma hakkının verilmesinin göçmenlerin siyasal alanda faaliyet göstermelerini olumsuz biçimde etkileyeceğini ve siyasal bütünleşme konusunda pasif bir tavır geliştirmelerinde etkili olacağını savunmaktadır. Yanı sıra göçmenlere ve yabancılara gelişigüzel biçimde verilen oy kullanma haklarının ulusal kimliği ve devlete bağl1lı̆̆1 ciddi biçimde sarsacağı ve bu yüzden yurttaşlık verme politikalarının sıkı biçimde uygulanması gerektiği düşünülmektedir (Byrne, 2018). Bu konuda ortaya çıkan sorunlardan ve risklerden birisi ise yerel düzeyde göçmen olanların oranının yerli halktan daha yüksek olduğu yerlerde görülmektedir. Oy kullanma hakkına sahip olan göçmenler veya yabancılar yerel siyasetteki dengeleri farklı biçimlerde etkileyebilmekte ve merkezi yönetimler ile bir takım uyumsuzlukların ortaya çıkmasına zemin hazırlamaktadır (Bauböck, 2005). Özellikle göçmen hareketinin güzergâhı üzerinde yer alan transit ülkelerde göçmenlerin siyasal katılımı ve yurttaşlık verme politikaları ile ilgili yasalar daha katı biçimde uygulanmaktadır. Transit ülkeler olarak kabul edilen ülkelerde göç hareketliliği ve yoğunluğu fazladır. Göçmenlere söz konusu hakların verilmesi ise bu ülkelerde demografik, sosyal, kültürel, siyasal ve ekonomik alanlarda ulusal sorunlara ve aynı zamanda göçün hedefi ile transit ülke arasında tartışmalı uluslararası sorunlara yol açmaktadır (Vasile ve Androniceanu, 2018).

Bir ülkede gerçekleşen seçimlere katılmak, sivil toplumun siyasal katılımını ve demokratik tutumunu göstermesi bakımından önemli bir göstergedir. Bundan dolayı göçmenlerin seçimlerde oy kullanıp kullanmaması hükümetlerin ve siyasal partilerin göçmen ve yurttaşlarla etkileşimini belirleyen bir stratejidir. Bu strateji, her iki grubu eşgüdümlü bir biçimde etkilemektedir. Doğal yurttaş olarak bilinenlerin oy verme eğilimi, aynı şekilde göçmen olanların eğilimlerini de etkilemektedir. Dolayısıyla göçmen karşıtı söylemlere sahip olan partilere ideolojik bir yakınlık olsa bile, göçmenlerin oy vermediği gözlenmiştir (Hainmueller ve Hopkins, 2014). Göçmenler yabancı olarak bulundukları ülkede sosyoekonomik koşullarını daha da iyileştireceğini vaat eden siyasal yapılara 
yönelmektedir. Bu durum ise oy dağılımını ve seçim sonuçlarını önemli ölçüde etkilemektedir. Almanya'da yaşayan Türk kökenli göçmenlerin seçim dönemlerinde -muhafazakâr olmasına rağmen- ekseriyetin sol partilere özellikle Almanya Sosyal Demokrat Partisine (Sozialdemokratische Partei Deutschlands) oy verdiği bilinmektedir. Bunun en belirgin sebebi ise Alman sağcı ve muhafazakâr partilerin öncü kültür vurgusu ve yabancılara yurttaşlık verilmesi konusundaki olumsuz tavırlarıdır (Erdoğan, 2015). Benzer bir durum ABD’ de yaşayan Latin ve Asya kökenli göçmenler ve yurttaşlık statüsüne sahip olanlar için geçerlidir. Latin ve Asya kökenliler ABD’de yapılan başkanlık seçimlerinde öteden beri Demokrat Parti'nin destekçileri olarak bilinmektedir. Ayrıca, Cumhuriyetçi Partinin adayları son yıllarda özellikle D. Trump, göçmen karşıtlı̆̆ı ile bilinmektedir (Min, 2014).

Demokrasilerde her zaman için azınlık konumunda olanların temsiliyeti önemli bir sorun teşkil etmiştir ve bu sorunun nasıl çözüme kavuşturulacağ1 konusunda çok sayıda alternatif düşünceler ileri sürülmüştür. Robert Dahl'a göre, çıkarları hükümetlerin icraatlarından ve aldığı kararlardan etkilendiği sürece insanlar, hükümetlerin belirlendiği süreçlere katılma hakkına sahip olmalıdır. "Etkilenen çıkarlar ilkesi” olarak bilinen bu özelliği savunan Dahl, demokratik bir yönetimin meşruiyetini sağlayan bir yönünü ortaya atmıştır. Bu ilke demokratik bir yönetimin kapsayıcılı̆̆ı söz konusu olduğunda köklü birtakım sonuçlar barındırır. Bir hükümetin almış olduğu siyasal kararlar, ülke içerisinde yaşayanlar kadar, ulusal sınırları aşarak, yurt dışında yaşayan yurttaşların ve bir sürü insanın çıkarlarını ve yaşantılarını etkileyebilmektedir (Dahl,1989, s.290). Bundan dolayı hükümetin icraatlarından çıkarları etkilenecek olan -yurttaş olsun veya olmasın- bir bireyin, yönetimin belirlendiği seçimlere katılma hakkı olmak zorundadır.

Siyasal bir hak olarak oy kullanmanın ulus devletin sınırlarını aştığ yegâne örnek Avrupa Birliği ülkeleridir. 1993 yılında varılan Maastricht Anlaşmasına göre $A B^{\prime}$ ye üye bir ülkenin yurttaşı, ikamet ettiği üye ülkelerin herhangi birinde oy kullanabilir. Avrupa Birliğine üye ülke yurttaşlarına tanınan bu hak, seçme ve seçilme hakkının sadece bir yurttaşlık hakkı olduğu yönündeki yaygın kanaate bir istisna teşkil etmektedir. Dünya genelinde demokratik yönetimlerin karşı karşıya geldiği krizlerden bir tanesi, yabancıların oy kullanması konusundaki sınırlamalardır. 
Göçmenlere ev sahipliği yapan ülke hükümetleri, göçmen ve yabancıları, oy kullanma veya siyasal katılım hakkı vermese bile tesis edilen kuruluşlar aracılığı ile karar alma süreçlerine dâhil edebilirler. AB üyesi 10 ülke (Belçika, Çekya, Estonya, Almanya, Danimarka, Finlandiya, İrlanda, İspanya, Portekiz ve Lüksemburg) göçmenler ile hükümet arasında bilgi alışverişi ve danışmanlık benzeri faaliyetleri yürüten kuruluşlar tesis etmişlerdir. Bu kuruluşlar göçmen sorunu ile ilgili farklı alanlarda çeşitli işlevleri yerine getirmektedir. Bu 10 ülkede göçmen ve yabancı nüfusunun yoğunlaştığı kentlerde yerel yönetimler söz konusu kuruluşlar aracılığ ile kentsel alanlarda karşılaşılan barınma, istihdam ve eğitim gibi sorunlar ile baş etmeye çalışmakta, sosyal bütünleşme ve siyasal temsil gibi konularda yurttaşlar ile yurttaş olmayanlar arasında bir diyalog kurabilmenin yollarını geliştirmişlerdir (EUFRA, 2017). Dünya genelinde, yoığun biçimde göç alan ülkelerde benzer kurumların tesis edilmesi, göçmenler ile yerli halklar arasında karşılıklı etkileşim ve diyalog sürecini, toplumsal uyumu ve demokratik bir kültürü daha da geliştirtirecektir.

\section{Göç ve Çokkültürrcülük}

Çokkültürcülük, bütün kültürleri ve kültürel yapıları birbirine eş gören ve belirli bir kültürü diğerlerinden üstün veya aşağı konumda görmeyen siyasal bir ideolojidir. Bu yönüyle çokkültürcülük evrenselci bir yaklaşım olup bireylerin devlet ile bütünleşmesi için kendi topluluk bağlarından tamamen kopması zorunluluğunu reddeder ve bireylerin farklı etnik ve kültürel gruplara dâhil olmasına rağmen aynı ulusun üyeleri olduğu düşüncesini savunur (Parekh, 2000, 7). Bir diğer ifadeyle devlet, bireylerin saygınlığının, ait oldukları topluluğun ortak saygınlığı ile bağlantılı olduğunu kabul eder. Burada bahsedilen ulus kavramı etnik, kültürel, dilsel, dinsel vb farklılıkların bir arada yaşamasını anayasal bir hak olarak gören ve aynı toprak parçası üzerinde yaşayan insanların birliği anlamında kullanılmaktadır. Çokkültürcülük, farklı kültürel yapıları bünyesinde barındırdığı için paylaşılan-ortak bir kültüre gereksinim duyar. Bu kültür ise ancak farklı kültürlerin birbirileri ile etkileşimi sonucunda oluşabilir. Ulus devletin sınırları içerisinde uygulanan bir siyasal ideoloji olarak bu yaklaşım, uluslar arası alanda ise farklı bir içeriğe 
sahiptir. Çünkü günümüz dünyasında çokkültürcülük sadece belirli bir devletin içinde yaşayan farklı grupları değil, başka bir dil, din, etnisite ve kültüre sahip bir ulus devlete bağlı olup da başka bir ulus devlette yaşayan insanları da ihtiva eden bir kavram haline gelmiştir (Kymlicka, 2002).

Tarihsel süreç içerisinde pek çok devlet yönetimi, ülkede bulunan farklı özelliklere sahip azınlık grupları, kendi varoluşları açısından bir tehdit unsuru olarak görmüştür. Bundan dolayı bu grupların başka bir ülkeye gitmesi, yok olması veya egemen kültüre asimile edilmeleri isteğini taşımıştır. Oysa bu durum oldukça zordur ve dünyada bu tür uygulamaların başarılı olduğunu görmek neredeyse imkansızdır. Özellikle yoğun göçler sonucunda belirli ülkelerde farklı özellikler taşıyan grupların sayısı git gide artış göstermektedir. Yaygın bir durum olarak bir ülkede bulunan göçmen ile azınlık konumundaki grupların doğurganlık oranı daha yüksektir. Bazı yönetimler bu durumun kendi kültürleri için bir tehdit olduğunu düşünmekte bazıları ise gittikçe düşen doğurganlık sonucunda ihtiyaç duyulan emek gücünün karşılanmasında işlevsel olacağını ileri sürmektedir. Her iki düşüncenin savunulduğu ülkelerde göçmenlerin sayısı hızla artmış, çok sayıda kent, çok kültürlü bir görünüme kavuşmuştur. Belli başlı kentlerde yerel, ulusal ve ulusal ötesi nitelik taşıyan pek çok pratik bir arada gözlemlenir hale gelmiştir (Schiller ve Çağlar, 2013). Farklı kültürel özellikler taşıyan pek çok insan, yeni bir sosyal ilişkiler ağı ve ekonomik faaliyet alanlarının ortaya çıkmasını sağlamıştır. Bundan dolayı uluslararası kuruluşlar ile ulusal ve yerel yöneticiler, kentlerde göçmenlerin var olan toplumsal düzene nasıl uyum sağlayacağı veya entegre edileceği ile ilgili çeşitli arayışlara yönelmişlerdir.

Şüphesiz artarak devam eden göç hareketlerine karşı devlet ve hükümetlerin toplumsal düzeyde oluşan ayrışmaları ve farklılaşmaları yeniden düzenleyebilmesi için bir takım önlemler alması zorunludur. Çünkü doğası gereği göç hareketlerinin sonucunda kültürel çeşitlilik ve farklılıklar önlenemez bir sosyal gerçekliğe dönüşebilmektedir. Almanya başbakanı Angela Merkel, 2010 yılında yaptığı bir açıklamada, çokkültürcülüğün tamamen başarısızlığa uğradığını, Almanya'da yaşayan göçmenlerin Alman toplumu ile bütünleşmeleri için daha fazla şey yapmaları gerektiğini dile getirmiştir. Bir yıl sonra İngiltere başbakanı 
David Cameron da, İngiltere'nin uzun yıllar boyunca uygulamaya çalıştığ1 çokkültürcülük politikasının, göçmenlerin şiddet eğilimli ideolojilere yönelmesi ve Britanya'nın kolektif kimliğine uyum sağlayamamış olmalarından ötürü, aynı şekilde başarısızlıkla sonuçlandığını ifade etmiştir (Green ve Staerkle, 2013, s.852). Avrupa'nın en çok göç alan iki ülkesinin başbakanlarının bu açıklaması, gelişmiş ülkelerde çokkültürcülük politikalarının gelmiş olduğu aşamayı göstermesi bakımından önemlidir. Ayrıca bu ülkelerde karşılaşılan yoğun göç akımlarının sadece göç alan devletlerin bir sorunu olmadığını, aynı zamanda uluslar arası ilişkileri etkileyen karmaşık bir sorun olduğunu ortaya koymaktadir.

Uluslar arası bir kuruluş olarak BM'nin Genel Sekreteri Antonio Guterres ise göreve başladığı 2017 yılında; ülkelerin çokkültürcülük politikası çerçevesinde göçmenlere kucak açması gerektiğini belirtmiştir. Ona göre çokkültürcülük, küresel ekonomik ve kültürel büyümenin anahtarıdır buna karşılık ayrıştırıcı ve dışlayıcı ulus devlet anlayışı, hâlihazırdaki gerçeklikler ile örtüşmemektedir. Milyonlarca insan hayatlarını riske atarak ve pek çok fedakarlıklar yaparak göç sürecine dâhil olmaktadır. Devletlerin elbette kendi sınırlarını ve yurttaşlarını koruma görevleri vardır fakat aynı zamanda savunmasız ve elverişsiz koşullar içinde bulunan göçmenlerin de temel ihtiyaçlarının giderilmesi ve yardım alması gereklidir. Bu düşünceleri dile getirmekle Guterres, göçün yol açtığ1 gerilimlerin; demokratik hoşgörü, tolerans ve insan haklarını ön plana çıaran değerlerle aşılabileceğini deklare etmiştir (UN 2017).

Demokrasinin ve insan haklarının gelişmesi ve daha etkin bir biçimde işleyebilmesi, toplumsal birlikteliğin sağlanması ile yakından ilişkilidir. Ulusal veya yerel ölçekte çokkültürcülük politikalarının ve anlayışlarının, yoğun göçlerden ötürü, başarısızlığa uğradığının iddia edilmesi, demokrasinin ve sosyal yapının geleceğini tehdit edici bir söylemdir. Bu söylem, toplumsal yapıdaki farklı gruplar arasındaki ayrışmaları ve kutuplaşmaları beraberinde getirmektedir. Dolayısıyla göçlerin yol açtığ 1 sorunların aşılması, hükümet politikalarının ve uluslar arası toplumun birlikte hareket etmesini zorunlu kılmaktadır.

\section{Sonuç}


Modern olarak kabul edilen demokratik devletlerin çoğunun çeşitli göçlerle oluştuğu bilinmektedir. Avrupa, Avusturalya ve büyük ölçüde Amerika kıtası başta olmak üzere dünyanın bir çok ülkesi, farklı yerlerden gelen insanlarla kurulmuştur. Buralarda yaşayan farklı etnik, din, dil ve kültürel özelliklere sahip grupların varlığı, büyük ölçüde kapsayıcı ve farklılıkları kabul eden siyasal ve sosyal bir anlayışın tesis edilmiş olması ile mümkün hale gelmiştir. Bu anlayışın temsil edildiği en iyi yönetim biçiminin demokrasi olduğu düşünülmektedir. Demokrasi, modern zamanların bir yönetim biçimi olarak, tüm insanların eşit haklara sahip olduğu ilkesine dayalıdır.

Ne varki son yıllarda küresel çapta yaşanan göçler, yine küresel nitelik taşıyan krizlere yol açar hale gelmiştir. Özellikle gelişmiş ve gelişmekte olan ülkelere yönelen göç hareketleri, son yıllarda yaşanan ekonomik sorunlarla bir araya geldiğinde, kamuoyunda ve siyasal alanda radikal bir takım düşüncelerin oluşmasına yol açmaktadır. Gelişmiş demokratik yönetimlere sahip olduğu bilinen ülkelerde, bizatihi kendisi de bir zamanlar göçmen olarak bilinen topluluk mensuplarının göçmen karşıtlığg, yabancı düşmanlığ 1 ve populist sağcı partilerin yükselme eğiliminde olması, demokrasinin değerlerinin tehlikeye girmekte olduğunun bir göstergesidir. Demokratik yönetim biçimlerinin tesis edilmesi, hiç kolay olmamıştır. Bir çok ülkede, yoğun mücadeleler ve çabalar sonucunda demokrasinin zaferi ilan edilmiştir.

Göçler, birey ve grupların sadece yaşam alanlarını değiştirmesi hareketinden ibaret değildir, beraberinde sosyal, siyasal, ekonomik, dinsel ve kültürel bakımdan son derece karmaşık ilişkiler ağını getirmektedir. Bundan dolayı bu özelliklerin yegane taşıyıcısı olan bireylerin, yeni toplumla uyum sağlayabilmelerinin kapasitesi arttırılmalıdır. Göçmen veya yabancılar, kendilerine özgü kimlik ve aidiyetlerin, başkaları açısından bir tehdit unsuru oluşturmadığını, aynı şekilde diğerleri ile asgari düzeyde olsa bile ortak paylaşımlar çerçevesinde bir birlik oluşturabileceklerinin imkanlarına sahip olmalıdırlar.

Tarihsel bir sorun olarak göç sonucunda oluşan sorunlar toplumsal kabul, bütünleşme ve uyum sayesinde aşılabilir bu da doğal olarak çokkültürcülüğü beraberinde getirir. Her ne kadar Almanya ve İngiltere gibi bazı ülkeler, göçlerin zorunlu kıldığı mali harcamaların yükünü 
hafifletmek amacıyla çokkültürcülük politikalarının başarısızlı̆̆a uğradığını ilan etse de, çokkültürcülük politikaları demokrasinin gelişmesinin temel dinamiklerinden birisidir. Bundan dolayı göçmen veya yabancı statüsünde bulunanların, yerel düzeyde başlamak üzere demokrasinin gerektirdiği temel ilkeler çerçevesinde, yasal bir statüye kavuşturulması ve yurttaşlık hakları konusunda bilinçlendirilmesi önemlidir. 


\title{
EXTENDED ABSTRACT
}

\section{Migration and the Future of Democracy}

*

\author{
Fethi Nas \\ BartınUniversity
}

In recent years, especially in developed and developing countries, migration has been among the most important issues on the agenda. From the regulation of the education system to the practices of religious life, from economic investments to resettlement policies, the necessity of considering the position of immigrants within the country has emerged in many fields and activities. Especially in countries governed by democracy, political parties are divided into two parts in terms of their attitudes towards immigrants. While some political parties have included programs to prevent and deport migrants, some opposing parties have emphasized that softer policies on migrants should be pursued. The first kind of parties, where anti-immigrant movements are intensified, criticize the migration policy of the governments that open the door to immigrants, claiming that immigrants threaten social order and cause various unrest in society. Other parties argue that immigrants will have a positive impact on the development of the country, taking into account the benefits of immigrants to the country's culture and economy. From this perspective, it is seen that migration and immigration issues have become a central topic in public debates and become a global crisis that continues to rise. Various changes that lead to economic and social problems along with the globalization process have revealed factors that push people to migrate.

Changing policies on migrants are being implemented in different countries. The most prominent ones have emerged in the European Union. Since the Second World War, the most important problems affecting the political perspectives of Western democracies have become the migration. European countries try to reduce the impact of migration movements as much as possible. Although the general tendency towards immigrants across Europe is not known exactly, it is possible to say that anti-immigrant movements are on the rise. Most of the government and political parties under the umbrella of the European Union have turned to restrictive migration policies in order to prevent the migration flows they face. In fact, the election success of the parties and leaders who support anti-immigration, especially in Europe and the 
United States, showed the importance of migration in political and economic discourse. In 2016, Donald J. Trump won the presidential election with his campaign against immigration. After the election, the Trump administration imposed restrictions on the entry of Muslim nationals into the United States and built a wall at the border against Mexican immigrants. So that it could be sad that there has been an increase in xenophobia and anti-immigration movements in the United States. In other countries which are known to be a traditional migration country, there are different practices for migration. For example, immigration policies in Australia focus on distinguishing between qualified and unskilled migration. While the arrival of skilled and educated migrants is encouraged, entry of unskilled migrants is restricted. On the contrary Canada, on the other hand, has adopted a multicultural migration policy that accepts many immigrants and refugees.

The immigration movements and the discussions about it has have brought about a dilemma around the world. This dilemma is related to the arguments developed by politicians for the migration problem, especially in countries known as democratic societies. Migration policies either bring multiculturalism or lead to polarization at the social level. Social institutions and processes in the receiving countries necessitate the implementation of various policies and practices in order to sustain the lives of migrants. It is known that most of the democratic states that are accepted as modern are formed by various migration flows. Many countries in the world, especially Europe, Australia and the Americas, have been established by people from different origins. The existence of groups with different ethnic, religious, linguistic and cultural characteristics living in these countries has become possible with the establishment of a political and social understanding that accepts differences. It is thought that democracy is the best form of government in which this understanding is represented. Democracy, as a form of government in modern times, is based on the principle that all people have equal rights. However, global migration in recent years has led to global crises. Especially when the migration movements towards developed and developing countries come together with the economic problems experienced in recent years, leaded to radical ideas in the public and political spheres. Anti-immigration, xenophobia and the rise of populist right-wing parties, in countries known to have developed democratic administrations; once known as immigrants countries, are an indication that the values of democracy are endangered. It has never been easy to establish democratic forms of governance. In many countries, the 
victory of democracy has been declared as a result of intense struggles and efforts. Migrations are not only a movement of individuals and groups to change their living spaces, but also bring together a very complex network of social, political, economic, religious and cultural relations. Therefore, the capacity of individuals who are the only carriers of these characteristics to adapt to the new society should be increased. Immigrants or foreigners should have the idea that their unique identity and belonging do not pose a threat to others, and even at a minimum level they can form uniformity with others.

As a historical problem, the problems that arise as a result of migration can be overcome by social acceptance, integration and harmony, which naturally brings together multiculturalism. Although some countries, such as Germany and the United Kingdom, have declared the failure of multiculturalism policies to alleviate the burden of financial expenses imposed by migration, multiculturalism policies are one of the fundamental dynamics of the development of democracy. Therefore, it is important to raise the awareness among immigrants or foreigners beginning at a local level that they have a legal status and the right of citizenship within the framework of the basic principles required by democracy.

\section{Kaynakça / References}

Bauböck, R. (2005). Expansive Citizenship-Voting Beyond Territory And Membership.Political Science and Politics, 38(4), 683-87.

Breunig, C.,Cao, X nndLuedtke A.,(2012). Global Migration And Political Regimetype: A Democratic Disadvantage. British Journal of Political Science, Cambridge University Press. 42(4), 825-854.

Byrne, J.(2018). National Identity And Migration In An Emerging Gateway Community, MDPI Social Science, 7(5), 73.

Dahl, R.A., 1989. Democracy and Its Critics. New Haven: Yale University Press.

De Genova ve Nicholas P. (2002). Migrant "Illegality" and Deportability In Everyday Life. Annual Review of Anthropology, 31, 419-47.

Engdahl, M., Lindgren, K. O., \& Rosenqvist, O. (2018). The role of local voting rights for foreign citizens : A catalyst for integration?, (Working Paper Series:2018:3), IFAU - Institute for Evaluation of Labour Market and Education Policy. 
Erdoğan, M. M. (2015). Avrupa'da Türkiye Kökenli Göçmenler Ve 'Euro-Turks Barometre' Araştırmaları. Göç Araştırmaları Dergisi, 1(1), 108-148.

Estevens, J.(2018). Migration CRISIs in the EU: Developing a Framework For Analysis Of National Security And Defence Strategies. Comparative Migration Studies 6. Article Number 28.

EUFRA (European Union Agency for Fundamental Rights). (2017). Together in the EU: Promoting the Participation of Migrants and their Descendants, Vienna.

European Commission. (2004). Common Basic Principles for Immigrant Integration Policy in the EU.

Forrester, A.C., Powell, B., Nowrasteh, A. ve Landgrave, M. (2019). Do Immigrants Import Terrorism? CATO Institute Working Paper.

Fukuyama, F., (2006). Identity, Immigrationand Liberal Democracy, Journal of Democracy, 17(2), 5-19.

Green, E.G.T., ve Staerklé, C. (2013). Migration and Multiculturalism. In Oxford Handbook of Political Psychology. UK: Oxford University Press.

Hainmueller, J. ve Hopkins, D.J. (2014). Public Attitudes Toward Immigration. The Annual Review of Political Science, 17, 225-249.

Huddleston, T., Bilgili, Ö., Joki, A. L. ve Vankova, Z., (2015). Migrant Integration Policy Index, 24.02.2018 tarihinde http://mipex.eu/political-participation adresinden erişilmiştir.

Hyde, A., vd. (2013). Why Don't They Naturalise? Voices from the Dominican Community, Latino Studies, 11(3), 313-40.

Inci, E.I. (2017). Postmodern discourse analysis of citizenshiptests: the cases of the United States of America and the United Kingdom.Marmara Journal Of European Studies, 25(2), 103-130.

Kılıç, S., Saharso, S. ve Sauer, B., (2008). Introduction: The veil: Debating citizenship, gender, and religious diversity. Social Politics, 15(4), 397-410.

Koslowski, R. (2002). Challenges of international cooperation in a world of increasing dual nationalityin rights and duties of dual nationals evolution and prospects. New York: Kluwer Law International,

Kymlicka, W. (2002). Multiculturalism and Minority Rights: West and East. Journal on Ethnopolitics and Minority Issues in Europe, Issue 4. 
Lizzeri, A.ve Persico, N. (2004). Why did the elites extend the suffrage? Democracy and the scope of government, with an application to Britain's "age of reform". The Quarterly Journal of Economics, 119( 2), 707-765.

McLaren, L. M., (2010). Cause for concern? The Impact Of Immigration On Politicaltrust. Policy Network Paper, University of Nottingham.

Medrzycki, K. (2017). Pioneering new immigration policy in the contemporary Japan. Göç Araştırmaları Dergisi, 3(1), 68-93.

Miller, A. H. ve Listhaug, O. (1990). Political parties and confidence in government: a comparison of Norway, Sweden and the United States.British Journal of Political Science, 29(3), 357-386.

Min, T.E.(2014). Thevimpact of panethnicity on Asian American and Latino political participation. Ethnicities, 14(5), 698-721.

Parekh, B.C. (2000), Rethinking Multiculturalism: Cultural Diversity and Political Theory. Harvard University Press.

Pedroza, L. (2015). The Democratic potential of enfranchising resident migrants, International Migration, 53(3), 23-24.

Podobnik, B., Jusup, M., Kovac, D., ve Stanley, H.E. (2016). Predicting the Rise of EU Right-Wing Populism in Response to Unbalanced Immigration. Complexity, 2017, 1580526:1-1580526:12.

Saurer, J. (2017). The acquisition of citizenship in the OECD Countries. IFO DICE Report $2,15$.

Schiller, N.G. ve Çağlar, A. (2013). Locating migrant pathways of economic emplacement: Thinking beyond the ethnic lens. Ethnicities, 13(4), 494-514.

Tuna, M. ve Özbek, Ç.(2014). Uluslararası göçler sonrası kimlik tartışmaları ve alternatif iki model: Çok-kültürlülük ve Avrupa Birliği Yurttaşlığı, yurttaşlığı yeniden düşünmek: sosyolojik hukuki.Siyasal Tartışmalar içinde. İstanbul: Bilgi Üniversitesi Yayınları.

United Nations (2017). Secretary-General Calls Migration Potential Solution To Many Global Challenges, Meetings Coverage and Press Releases. 16 February.

United Nations (UN), (2016). International Migration 2015, department for economic and social affairs, Population Division. 
Vasile, O. ve Androniceanu, A. (2018). An Overview Of The Romanian Asylum Policies, Sustainability, 10 (5), 1461-1489.

Verea, M. (2018). Anti-immigrantand anti-Mexican attitudes and policies during the first 18 months of the Trump administration sentimientos. Norteamérica, 13 (2).

Wadsworth, J.,Dhingra, S., Ottaviano, G., ve Van Reenen, J. (2016). Brexit and the Impact Of Immigration on the UK, Center for Economic Performance. London School of Eonomics and Political Science.

Weldon, S. A. (2006). the institutional context of tolerance for ethnic minorities: A Comparative, multi-level analysis of Western Europe. American Journal of Political Science, 50(2), 331-349.

White, S., Nevitte, N., Blais, A., Gidengil, E., ve Fournier, P. (2008). The political resocialization of immigrants: Resistance or lifelong learning?. Political Research Quarterly, 61(2), 268-281.

Wittenberg, L., (2017). Managing Mixed Migration: The Central Mediterranean Route To Europe, International Peace Institute Desperate Migration Series. No. 3, April.

\section{Kaynakça Bilgisi / Citation Information}

Nas, F. (2019). Göç ve Demokrasinin Geleceği. OPUS-Uluslararası Toplum Araştırmları Dergisi, 13(19), 2125-2149. DOI:10.26466/opus. 592954. 